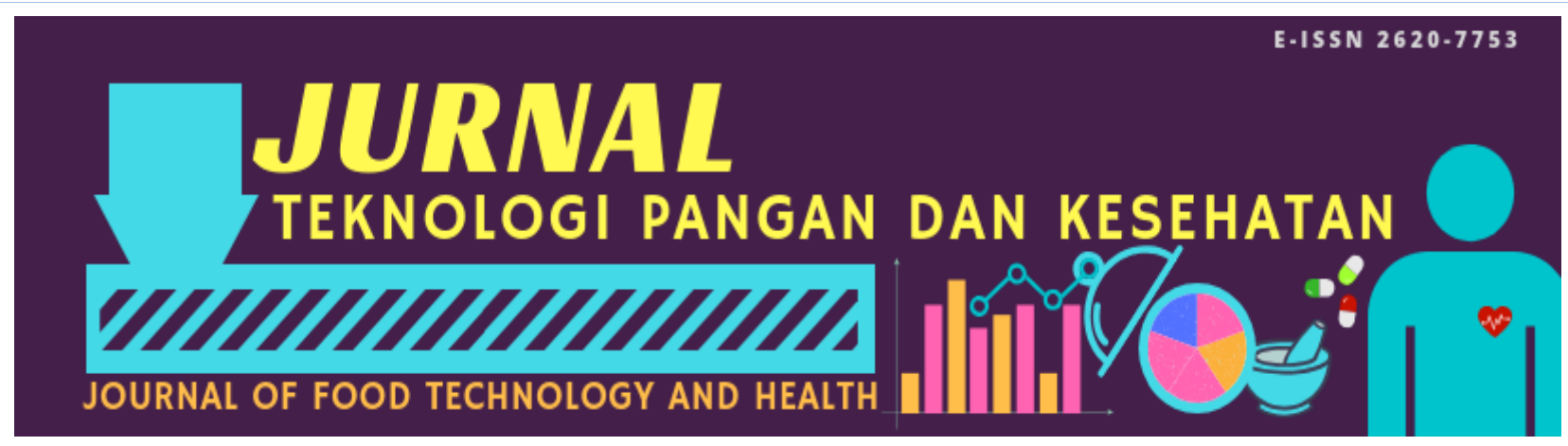

Volume I Nomor 2 Tahun 2019

Hasil Penelitian

Diterima 3 Sep 2019

Disetujui 26 Des 2019

\title{
OPTIMASI KAPASITAS ANTIOKSIDAN KECAMBAH KEDELAI VARIETAS WILIS
}

\author{
Wenny Silvia Loren Boru Sinaga ${ }^{* 1}$, Azis Boing Sitanggang ${ }^{2}$, Jessica ${ }^{1}$ \\ ${ }^{1}$ Universitas Pelita Harapan, Gedung B Lt. 5 Kantor FaST, Jl. M.H. Thamrin Boulevard 1100, \\ Kelapa Dua, Karawaci, Kota Tangerang Banten 15811 \\ ${ }_{2}^{2}$ Institut Pertanian Bogor, Gedung Fateta, Kampus IPB Darmaga. PO BOX 220, Bogor 16002
}

\begin{abstract}
ABSTRAK: Kedelai adalah produk pangan bernilai gizi tinggi yang banyak dikonsumsi oleh masyarakat Indonesia. Pada penelitian ini, kedelai dimodifikasi dengan cara perkecambahan. Komponen zat gizi akan berubah menjadi senyawa-senyawa yang lebih sederhana selama proses perkecambahan sehingga menjadi lebih mudah dicerna bagi tubuh manusia. Selain itu, perkecambahan juga dapat meningkatkan kapasitas antioksidan. Tujuan dari penelitian ini adalah menentukan kondisi perkecambahan untuk mengoptimalkan kapasitas antioksidan dari biji kedelai varietas Wilis. Hasil penelitian menunjukkan bahwa kondisi terbaik untuk mengoptimalkan kapasitas antioksidan adalah dengan cara perkecambahan pada suhu $25^{\circ} \mathrm{C}$ selama 15 jam dengan rasio biji kedelai dan air 1:3 tanpa adanya penambahan garam. Kapasitas antioksidan kecambah kedelai var. Wilis pada 100 ppm memiliki radical scavenging activity sebesar 9,69\% dengan scavenging ternormalisasi 0,65\% dengan total fenol 2,1 mg GAE/g pada biji dan 2,9 mg GAE/g pada kecambah. Dari hasil identifikasi GC-MS ditemukan senyawa-senyawa antioksidan yang terdapat pada biji kedelai dan kecambah kedelai berupa benzoic acid, 2-methoxy-4-vinylphenol, 2,5-dihydroxytoluene, pyrogallol 1,3-dimethyl ether, 2,5dihydroxytoluene, pyrogallol 1,3-dimethyl ether, hexadecanoic acid methyl ester dan methyl oleate serta terdapat juga senyawa-senyawa antioksidan baru yang muncul setelah proses perkecambahan yaitu neophytadiene, campesterol, stigmasterol, delta-tocopherol dan gamma-tocopherol.
\end{abstract}

Kata Kunci: Kedelai var. Wilis, Kecambah, Antioksidan, Rasio Air

ABSTRACT: Soybean is a high nutrition food product that is largely consumed by Indonesians. In this research, the soybean will be modified by going through the germination process. Complex nutrition would be changed into substances that were more simple during the germination process. Therefore, it would be easier for human to digest it. Moreover, this process might also increase the antioxidant capacity of the soybean itself. The aim of this research is to find out the most suitable germination condition in order to acquire the optimum antioxidant capacity of Wilis variety soybean. The result shows that the best condition to optimize the antioxidant capacity is by performing the germination process at $25^{\circ} \mathrm{C}$ for 15 hours with soybean to water ratio being 1:3 without any salt addition. The antioxidant capacity of Wilis soybean at 100 ppm has 9,69\% of radical scavenging activity, with 0,65\% being normalized. The total phenolic compound found in the beans was 2,1 $\mathrm{mg} \mathrm{GAE} / \mathrm{g}$, whereas 2,9 $\mathrm{mg} \mathrm{GAE} / \mathrm{g}$ were found in the sprout. Based on the GC-MS identification, the antioxidant compounds that are found in both the soybean and sprout are known to be benzoic acid, 2-methoxy-4-vinylphenol, 2,5-dihydroxytoluene, pyrogallol 1,3-dimethyl ether, 2,5-dihydroxytoluene, pyrogallol 1,3-dimethyl ether, hexadecanoic acid methyl ester, and methyl oleate. In addition, there are also several new antioxidant compounds that emerge after the germination process, which are neophytadiene, campesterol, stigmasterol, delta-tocopherol, and gamma-tocopherol.

Keywords: Soybean var. Wilis, Sprout, Antioxidant, Water Ratio

\section{PENDAHULUAN}

Kedelai merupakan salah satu produk pangan yang banyak dikonsumsi oleh masyarakat Indonesia karena memiliki banyak kelebihan seperti bernilai gizi tinggi. Dalam penelitian yang dilakukan oleh Ginting

\footnotetext{
*Email korespondensi: wenny.sinaga@uph.edu
} 
et al. (2009), terdapat varietas kedelai lokal unggul yaitu Wilis yang memiliki biji berwarna kuning, kadar protein tinggi serta intensitas langu rendah sehingga berpotensi untuk dikembangkan lebih lanjut. Salah satu cara yang dapat dilakukan adalah dengan memodifikasi kedelai melalui proses perkecambahan.

Perubahan komponen zat gizi menjadi senyawa-senyawa yang lebih sederhana terjadi selama perkecambahan sehingga lebih mudah dicerna oleh tubuh (Astawan, 2009). Kandungan zat gizi pada kedelai sebelum dikecambahkan berada dalam bentuk tidak aktif atau terikat dan akan diaktifkan setelah dikecambahkan sehingga meningkatkan daya cerna bagi tubuh manusia. Selain itu, selama proses perkecambahan juga akan terjadi peningkatan kapasitas antioksidan (Huang et al., 2014). Kedelai yang telah dikecambahkan akan mengalami peningkatan senyawa fenol dan vitamin E (Cevallos-Casals \& CisnerosZevallos, 2010; Plaza et al., 2003).

Pada penelitian ini dilakukan proses perkecambahan untuk mengetahui kondisi terbaik untuk mengoptimalkan kapasitas antioksidan kecambah kedelai. Proses perkecambahan terbaik akan ditentukan dari berbagai perlakuan seperti suhu perendaman, waktu perkecambahan, penambahan garam, serta rasio kedelai dan air yang diduga dapat mempengaruhi proses perkecambahan. Kecambah dengan kapasitas antioksidan terbaik beserta biji kedelai kemudian dianalisis lebih lanjut untuk mengetahui jenis kandungan antioksidan serta total fenol yang terkandung didalam biji dan kecambah kedelai tersebut.

\section{METODE PENELITIAN}

\section{Pengaruh Suhu Perendaman dan Lama Perkecambahan}

Tahap ini dilakukan untuk menentukan kondisi optimal unuk mendapatkan kapasitas antioksidan terbaik dari kombinasi perlakuan suhu perendaman dan lama perkecambahan yang berbeda.

Penelitian tahap ini diawali dengan proses penyortiran untuk memisahkan kedelai yang layak dengan kedelai tak layak pakai. Kedelai hasil sortasi selanjutnya direndam dalam air selama enam jam dengan kondisi awal berupa rasio kacang kedelai dan air adalah 1:4 tanpa adanya penambahan garam. Suhu perendaman divariasikan menjadi 25,35 dan $45^{\circ} \mathrm{C}$

Selama proses perendaman dihitung juga laju penyerapan air dan $\mathrm{pH}$ pada suhu rendaman tiap 3 jam. Setelah itu, kacang kedelai ditiriskan dan dimasukkan ke dalam wadah yang dialaskan kain kasa serta ditutup dengan kain hitam untuk dikecambahkan. Kain hitam disemprotkan dengan air setiap 24 jam perkecambahan untuk menjaga kelembaban kondisi perkecambahan. Lama perkecambahan divariasikan menjadi 15, 24, 39 dan 48 jam.

Perkecambahan dilakukan pada suhu ruang karena suhu optimum dari perkecambahan biji kedelai adalah sekitar $20-25^{\circ} \mathrm{C}$. Setelah itu, kecambah kedelai dari tiap perlakuan dihancurkan dengan blender menggunakan pelarut metanol dan dianalisis kapasitas antioksidannya menggunakan metode DPPH (Gambar 1).

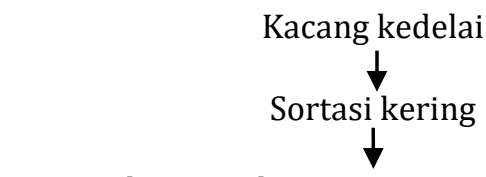

Perendaman selama enam jam dengan kondisi perendaman berupa rasio biji kedelai dan air 1:4 tanpa garam $\left(25,35\right.$ dan $\left.45^{\circ} \mathrm{C}\right)$
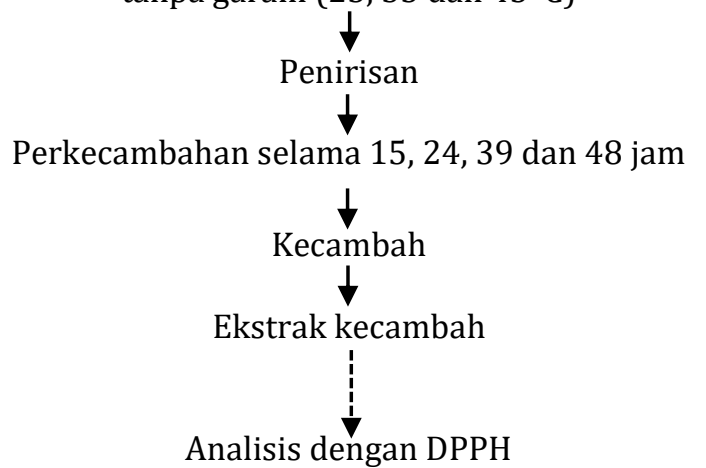

Gambar 1. Diagram alir metode perkecambahan untuk menentukan pengaruh suhu perendaman dan lama perkecambahan

\section{Pengaruh Penambahan Garam terhadap Antioksidan Kecambah Kedelai}

Tahap ini dilakukan untuk menentukan kondisi optimal untuk mendapatkan kecambah dengan kapasitas antioksidan terbaik dari pengaruh penambahan garam. 
Penelitian ini sama seperti penelitian pada tahap sebelumnya namun yang divariasikan adalah konsentrasi garam yaitu $0,1,2.5,5$ dan $10 \mathrm{~g} / \mathrm{L}$. Penelitian ini menggunakan suhu perendaman dan lama perkecambahan optimum pada tahap I dengan kondisi perendaman pada rasio biji kedelai dan air 1:4 selama enam jam.

\section{Pengaruh Rasio Biji Kedelai dan Air terhadap Antioksidan Kacang Kedelai}

Tahap ini dilakukan untuk menentukan kondisi optimal untuk mendapatkan kecambah dengan kapasitas antioksidan terbaik dari pengaruh kondisi perendaman berupa rasio kacang kedelai dan air. Penelitian ini sama seperti penelitian pada tahapan-tahapan sebelumnya namun yang divariasikan adalah kondisi perendaman berupa rasio kacang kedelai dan air yaitu 1:1, $1: 2,1: 3,1: 4,1: 5$, dan 1:6. Selama proses perendaman ini, suhu perendaman, lama perkecambahan dan konsentrasi penambahan garam optimum pada tahap I dan II digunakan bersama dengan lama perendaman selama enam jam.

\section{Uji kandungan Antioksidan dengan GC-MS}

Tahap ini dilakukan untuk mengetahui jenis kandungan antioksidan dalam biji dan kecambah kedelai dengan kapasitas antioksidan terbaik. Tahap ini diawali dengan ekstraksi terhadap biji kedelai dan kecambah kedelai yang memiliki kapasitas antioksidan terbaik menggunakan pelarut metanol untuk menganalisis jenis antioksidan yang terdapat didalamnya. Penelitian tahap ini kemudian dilanjutkan dengan metode GC-MS dengan kondisi yang tertera pada Tabel 1 .

Tabel 1. Kondisi GC-MS

\begin{tabular}{llcc}
\hline \multirow{2}{*}{ No } & Parameter & \multicolumn{2}{c}{ Kondisi } \\
\cline { 3 - 4 } & & Biji Kedelai & $\begin{array}{c}\text { Kecambah } \\
\text { Kedelai }\end{array}$ \\
\hline & & Agilent \\
& & $19091 \mathrm{~S}-$ & Agilent \\
1 & Column & 433 & $19091 \mathrm{~S}-433$ \\
2 & Pressure & $10.30 \mathrm{Psi}$ & $10.31 \mathrm{Psi}$ \\
3 & Flow rate & $1.0 \mathrm{~mL} / \mathrm{min}$ & $1.0 \mathrm{~mL} / \mathrm{min}$ \\
4 & Detector & $\mathrm{FID}$ & $\mathrm{FID}$ \\
5 & Carrier & $\mathrm{H} 2$ & $\mathrm{H} 2$ \\
6 & Temperature & $250^{\circ} \mathrm{C}$ & $250^{\circ} \mathrm{C}$ \\
7 & Run time & $50.43 \mathrm{~min}$ & $50.43 \mathrm{~min}$ \\
\hline
\end{tabular}

J. Teknol. Pangan Kes., 1(2), hal. 65-74

\section{Uji Total Fenolik}

Tahap yang dilakukan di Laboratorium IPB Farmaka ini diawali dengan melakukan ekstraksi terhadap kecambah kedelai terbaik dengan menggunakan pelarut metanol yang kemudian dilanjutkan dengan menganalisis kandungan total fenol yang terdapat di biji dan kecambah kedelai tersebut.

\section{Uji Kapasitas Antioksidan dengan Metode DPPH}

Sampel sebanyak $11 \mathrm{~g}$ diekstrak dengan cara dihancurkan menggunakan blender dengan pelarut metanol sebanyak $50 \mathrm{~mL}$. Selanjutnya, sampel disentrifugasi dengan kecepatan 6.000 rpm selama 5 menit. Sampel kemudian disaring dengan kertas saring untuk diambil filtratnya. Filtrat kemudian diencerkan kedalam 50 mL labu takar dengan pelarut metanol sampai batas miniskus sehingga didapatkan ekstrak dengan konsentrasi 100.000 ppm. Ekstrak sampel tersebut kemudian diambil lagi sebanyak 0,5 mL dan diencerkan ke dalam labu takar 50 $\mathrm{mL}$ sehingga didapatkan ekstrak dengan konsentrasi $1.000 \mathrm{ppm}$. Setelah itu, $5 \mathrm{~mL}$ ekstrak diambil lagi dan diencerkan ke dalam labu takar $50 \mathrm{ml}$ sehingga didapatkan ekstrak dengan konsentrasi $100 \mathrm{ppm}$. Ke dalam kuvet dimasukkan 2,5 mL campuran ekstrak sampel dan metanol serta $1 \mathrm{~mL}$ DPPH 0,2 mM. Larutan diinkubasi selama 30 menit dalam gelap pada suhu $37^{\circ} \mathrm{C}$, dan diukur serapannya pada panjang gelombang $517 \mathrm{~nm}$.

Persentase aktivitas antioksidan dihitung dengan persamaan:

\section{Radical Scavenging Activity (\%)}

$$
=\frac{\left(\mathrm{A}_{\text {kontrol }}-\mathrm{A}_{\text {sampel }}\right)}{\mathrm{A}_{\text {kontrol }}} \times 100 \%
$$

Radical scavenging ternormalisasi juga dihitungn untuk mengetahui tingkat produktivitas kapasitas antioksidan kecambah terbaik per jam selama proses perkecambahan dengan persamaan:

$$
\begin{aligned}
& \text { Radical Scavenging ternormalisasi (\%/jam) } \\
& =\frac{\% \text { Radical Scavenging Activity }}{\text { Waktu Perkecambahan (jam) }}
\end{aligned}
$$




\section{Uji Laju Penyerapan Air dan pH}

Analisis laju penyerapan air dilakukan dengan menimbang sampel $50 \mathrm{~g}$ sebagai berat awal. Selanjutnya, sampel dimasukkan kedalam wadah yang berisi air dan didiamkan selama 3 jam. Sampel kemudian ditiriskan dengan tissue dan dibiarkan selama 1 jam. Setelah itu, sampel ditimbang dan dihitung laju penyerapan airnya dengan persamaan:

Laju penyerapan air 3 jam perendaman

$$
=\frac{\mathrm{W}_{1}-\mathrm{W}_{0}}{3 \times 1000}
$$

Sampel kemudian direndam lagi selama 3 jam lalu ditiriskan selama 1 jam dan ditimbang lagi. Laju penyerapan air setelah 6 jam perendaman dihitung dengan persamaan:

Laju penyerapan air 6 jam perendaman

$$
=\frac{\mathrm{W}_{2}-\mathrm{W}_{1}}{3 \times 1000}
$$

Keterangan:

$\mathrm{W}_{0}$ : berat sampel awal $(\mathrm{g})$

$\mathrm{W}_{1}$ : berat sampel setelah 3jam perendaman (g)

$\mathrm{W}_{2}$ : berat sampel setelah 6 jam perendaman (g)

Air rendaman dari sampel juga diuji derajat keasamannya $(\mathrm{pH})$ menggunakan $\mathrm{pH}$ meter. $\mathrm{pH}$ meter digunakan dengan cara melakukan kalibrasi terlebih dahulu yaitu dengan mencelupkannya ke dalam larutan standar dengan $\mathrm{pH} 7$ dan 4 dan dicuci menggunakan akuades. Setelah itu, $\mathrm{pH}$ meter dicelupkan kedalam air rendaman untuk menguji derajat keasamannya.

\section{HASIL DAN PEMBAHASAN}

Proses fermentasi terjadi selama perkecambahan ketika menggunakan metode perendaman pada suhu 25, 35 dan $45^{\circ} \mathrm{C}$. Hal ini ditandai dengan terlihatnya busa setiap kali dilakukannya pergantian air serta jumlah busa yang semakin banyak dan $\mathrm{pH}$ pada air rendaman yang terus menurun seiring dengan berjalannya waktu. Selama proses perendaman akan terjadi proses fermentasi alami oleh bakteri asam laktat yang mengakibatkan meningkatnya tingkat keasaman (Nurdini et al., 2015). Hal ini disebabkan oleh terjadinya akumulasi asam laktat yang terbentuk oleh adanya pertumbuhan bakteri asam laktat (Narsih \& Harijono, 2008).

Kacang kedelai yang berkecambah dengan metode ini juga sedikit dan pendek serta terdapat banyak biji kacang kedelai yang pecah. Hal ini dapat disebabkan oleh terjadinya perubahan tekstur dari biji kedelai akibat penyerapan air saat direndam dalam jangka waktu yang lama (Pan \& Tangratanavalee, 2003). Maka dari itu, metode ini dimodifikasi lagi untuk mendapatkan metode perkecambahan yang lebih efektif.

\section{Pengaruh Suhu Air Rendaman dan Waktu Perkecambahan Terhadap Mutu Kecambah Kedelai var. Wilis}

Hasil analisis statistik menunjukkan hampir semua data antara kapasitas antioksidan kecambah kedelai var. Wilis berdasarkan suhu dan waktu berbeda signifikan $(\mathrm{p}<0.05)$.

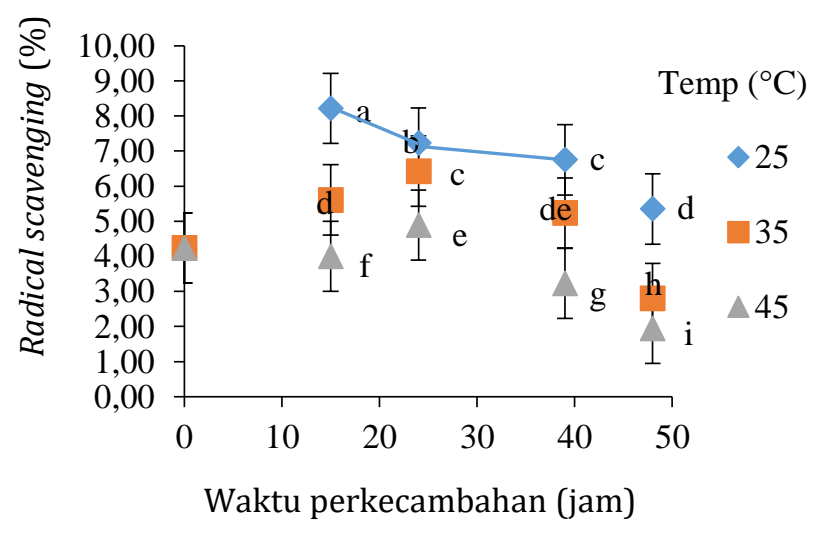

Gambar 2. Pengaruh lama waktu rendaman dan suhu air rendaman terhadap kapasitas antioksidan kecambah kedelai var. Wilis pada konsentrasi ekstrak kecambah kedelai 100 ppm dengan waktu perendaman 6 jam dan suhu perkecambahan $25^{\circ} \mathrm{C}$. Keterangan: Notasi huruf superscript yang berbeda menunjukkan adanya perbedaan signifikan $(\mathrm{p}<0.05)$

Gambar 2 menunjukkan bahwa kecambah kedelai var. Wilis dengan kapasitas antioksidan terbaik adalah kecambah yang diberi perlakuan suhu perendaman pada suhu ruang yang dikecambahkan selama 15 
jam. Hal ini sesuai dengan Wardani et al. (2014) yang menyatakan suhu optimum perkecambahan kacang kedelai adalah $25^{\circ} \mathrm{C}$. Menurut Larcher (2003), hal ini dikarenakan suhu yang semakin tinggi dapat menyebabkan pemecahan enzim dan pengurangan jumlah asam amino akibat sintesis RNA. Perkecambahan dalam jangka waktu pendek yaitu sekitar 6-24 jam juga dapat meningkatkan kapasitas antioksidan terutama total isoflavon (Kim et al., 2005). Namun, kapasitas antioksidan kemudian akan perlahan mengalami penurunan seiring dengan berjalannya waktu.

Hasil dari perkecambahan dengan metode ini kemudian dinormalisasikan untuk mengetahui tingkat produktivitas kapasitas antioksidan kecambah terbaik per jam selama proses perkecambahan. Berdasarkan Gambar 3 dapat disimpulkan bahwa hampir semua data antara kapasitas antioksidan ternormalisasi kecambah kedelai var. Wilis berdasarkan suhu dan waktu berbeda signifikan $(\mathrm{p}<0.05)$.

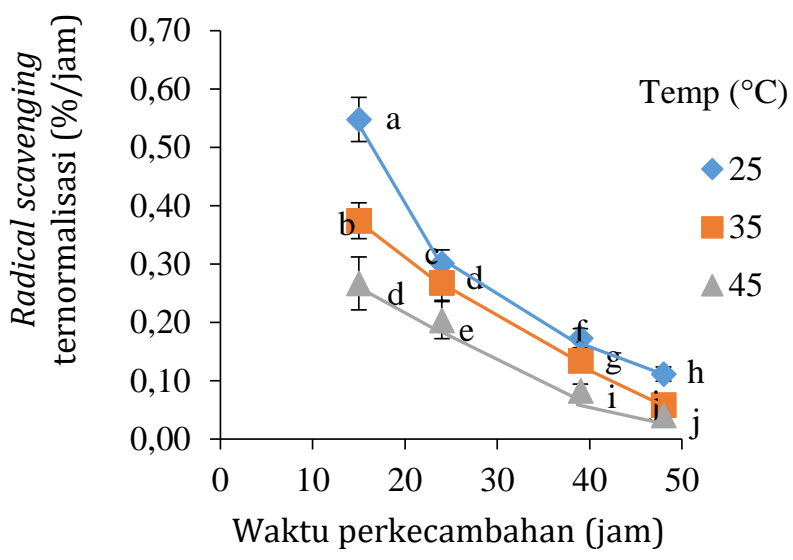

Gambar 3. Pengaruh lama waktu rendaman dan suhu air rendaman terhadap kapasitas antioksidan ternormalisasi kecambah kedelai var. Wilis pada konsentrasi ekstrak kecambah kedelai 100 ppm dengan waktu perendaman 6 jam dan suhu perkecambahan $25^{\circ} \mathrm{C}$. Keterangan: Notasi huruf superscript yang berbeda menunjukkan adanya perbedaan signifikan $(\mathrm{p}<0.05)$.

Kapasitas antioksidan terbaik juga terdapat pada perlakuan kombinasi suhu perendaman $25^{\circ} \mathrm{C}$ dan waktu perkecambahan 15 jam. Maka dari itu, kondisi ini yang digunakan pada tahapan selanjutnya untuk mendapatkan kondisi optimum perkecambahan.

Pada penelitian ini juga dihitung laju penyerapan air selama proses perendaman biji kedelai berlangsung. Perhitungan laju penyerapan air dilakukan setiap 3 jam sekali selama 6 jam. Gambar 4 menunjukkan laju penyerapan air tertinggi adalah pada suhu $45^{\circ} \mathrm{C}$ sedangkan laju penyerapan air terendah adalah pada suhu $25^{\circ} \mathrm{C}$. Hal ini sesuai dengan teori Shafaei et al. (2016) yang menyatakan bahwa suhu tinggi dapat meningkatkan difusivitas yang mengakibatkan lebih cepatnya laju penyerapan air. Peningkatan suhu akan mengakibatkan pelunakan jaringan biji kedelai sehingga tingkat permeabilitas membran sel lebih besar yang menyebabkan penyerapan air akan menjadi lebih besar (Wachid, 2006).

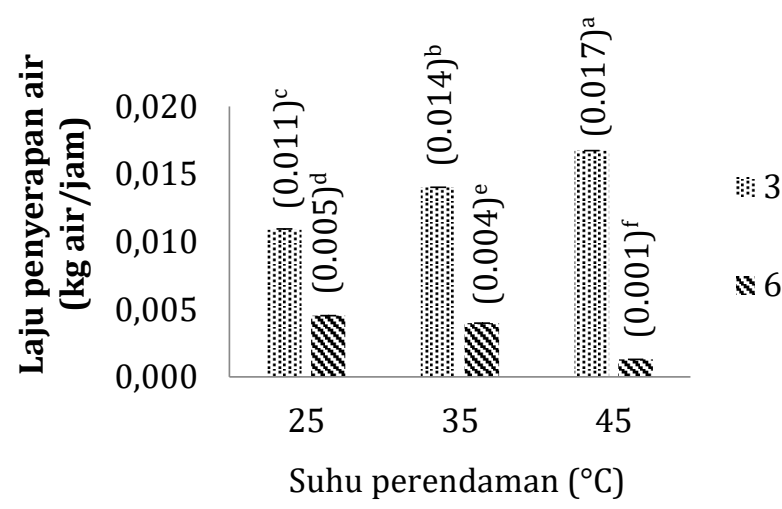

Gambar 4. Pengaruh perlakuan suhu terhadap laju penyerapan air kecambah kedelai var. Wilis

Dari Gambar 4 juga menunjukkan bahwa pada 3 jam pertama perendaman, laju penyerapan air meningkat cukup drastis. Hal ini dikarenakan adanya perbedaan konsentrasi yang cukup tinggi antara lingkungan dengan kondisi didalam biji sehingga terjadi proses difusi air dari luar atau lingkungan kedalam inti biji kedelai. Pada 3 jam perendaman selanjutnya, air tidak lagi berdifusi ke dalam inti biji melainkan hanya mengisi jaringan-jaringan permukaan biji.

Selain itu, juga dilakukan pengecekan $\mathrm{pH}$ pada tiap suhu setiap 3 jam perendaman. Gambar 5 menunjukkan bahwa perendaman pada suhu 35 dan $45^{\circ} \mathrm{C}$, pH air rendaman menurun cukup drastis dibandingkan $\mathrm{pH}$ air 
rendaman pada suhu $25^{\circ} \mathrm{C}$. Hal ini dikarenakan suhu optimum pertumbuhan dari bakteri asam laktat adalah sekitar $40^{\circ} \mathrm{C}$ sehingga semakin suhu air rendaman mendekati suhu $40^{\circ} \mathrm{C}$ maka semakin optimal bakteri asam laktat untuk melakukan fermentasi.

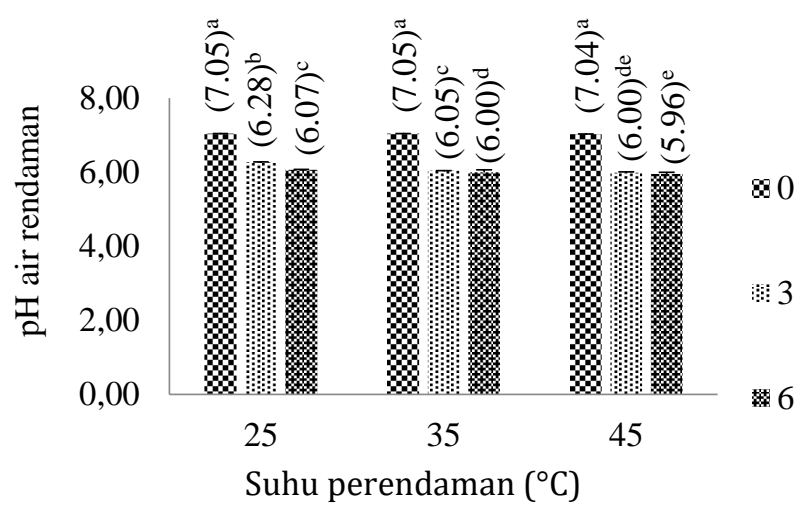

Gambar 5. Pengaruh perlakuan suhu terhadap pH air rendaman kecambah kedelai var. Wilis

Selain itu, pH pada 3 jam pertama mengalami penurunan $\mathrm{pH}$ yang cukup drastis dibandingkan $\mathrm{pH}$ pada 3 jam selanjutnya. Hal ini dapat disebabkan oleh laju penyerapan air pada 3 jam pertama lebih banyak dibandingkan laju penyerapan air pada 3 jam selanjutnya sehingga pemecahan molekul menjadi komponen-komponen asam lebih banyak terjadi pada 3 jam pertama dibandingkan 3 jam selanjutnya.

\section{Pengaruh Perlakuan Garam terhadap Mutu Kecambah Kedelai var. Wilis}

Hasil analisis statistik menunjukkan hampir semua data antara kapasitas antioksidan kecambah kedelai var. Wilis terhadap perlakuan penambahan garam berbeda signifikan $(\mathrm{p}<0.05)$.

Gambar 6 menunjukkan bahwa kecambah kedelai var. Wilis dengan kapasitas antioksidan terbaik adalah kecambah yang direndam tanpa garam. Hal ini dikarenakan penambahan garam dapat mempengaruhi pertumbuhan tanaman yaitu meningkatkan tekanan osmotik sehingga menghambat penyerapan air. Menurut Rosmarkam \& Yuwono (2002), tingginya jumlah garam dapat berdampak negatif pada pertumbuhan tanaman oleh karena tersedianya air tidak dapat digunakan oleh biji kedelai akibat tingginya tekanan osmosis yang dibutuhkan oleh biji kedelai.

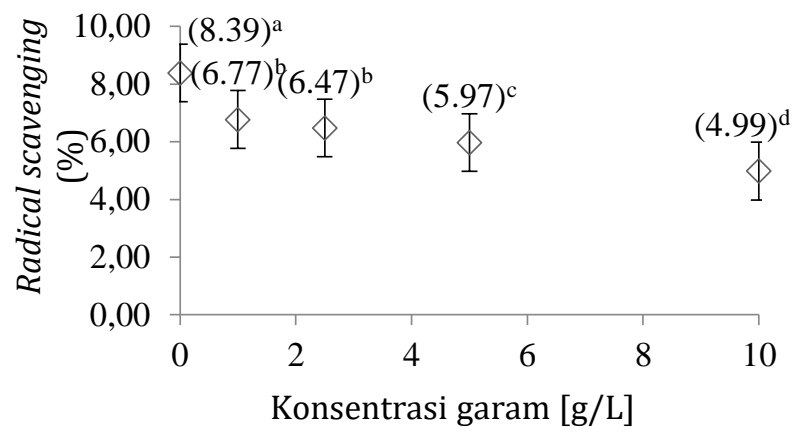

Gambar 6. Pengaruh penambahan garam terhadap kapasitas antioksidan kecambah kedelai var. Wilis pada konsentrasi ekstrak kecambah kedelai 100 ppm dengan waktu perendaman 6 jam, suhu perendaman $25^{\circ} \mathrm{C}$, waktu perkecambahan 15 jam dan suhu perkecambahan $25^{\circ} \mathrm{C}$. Keterangan: Notasi huruf superscript yang berbeda menunjukkan adanya perbedaan signifikan $(\mathrm{p}<0.05)$

Laju penyerapan air juga dihitung selama proses perendaman biji kedelai berlangsung. Perhitungan laju penyerapan air dilakukan setiap 3 jam sekali selama 6 jam.

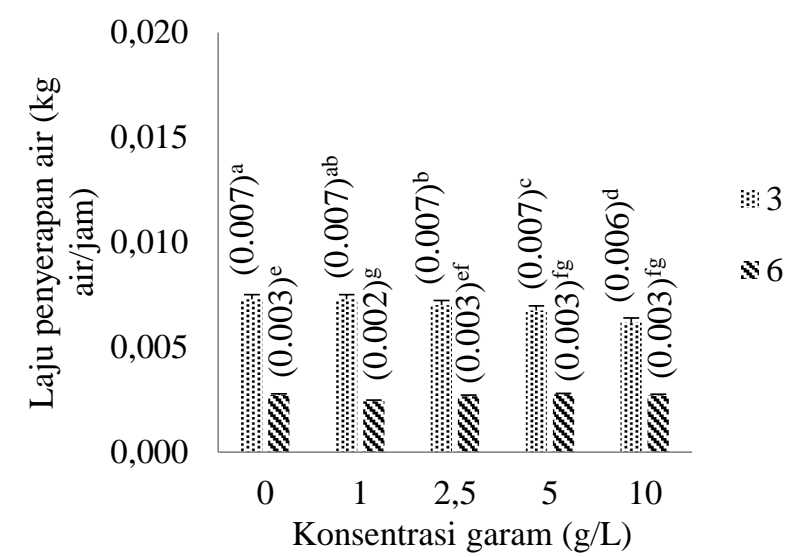

Gambar 7. Pengaruh penambahan garam terhadap laju penyerapan air kecambah kedelai var. Wilis

Gambar 7 menunjukkan bahwa adanya penambahan garam akan mengurangi jumlah serapan air dari biji kedelai. Hal ini dikarenakan sifat garam yang menghambat penyerapan air dengan terjadinya peningkatan tekanan osmotik. Hal yang sama juga terjadi pada laju penyerapan biji kedelai yang diberi perlakuan garam yaitu laju penyerapan air pada 3 jam pertama lebih 
tinggi dibandingkan laju penyerapan air 3 jam setelahnya.

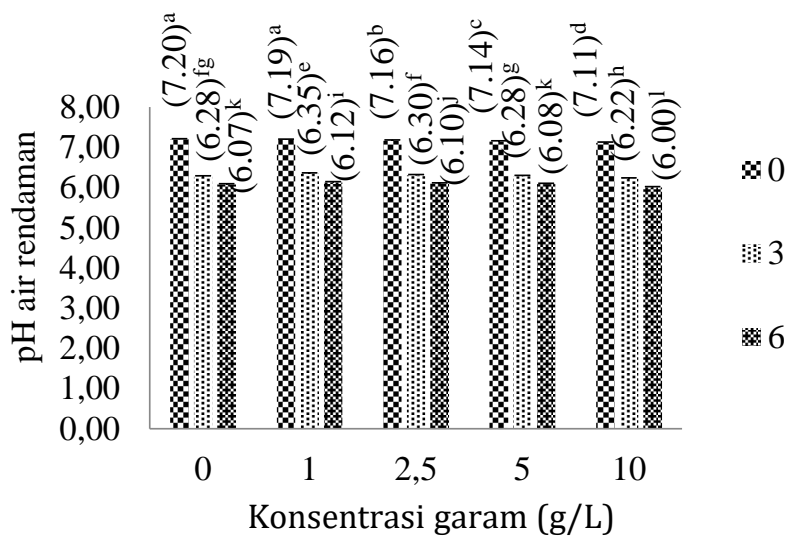

Gambar 8. Pengaruh penambahan garam terhadap pH air rendaman kecambah kedelai var. Wilis

Selain itu, juga dilakukan pengecekan $\mathrm{pH}$ pada tiap suhu setiap 3 jam perendaman. Gambar 8 menunjukkan bahwa semakin banyak penambahan kadar garam maka semakin rendah $\mathrm{pH}$ air rendaman $\mathrm{Hal}$ ini dapat terjadi karena bakteri asam laktat merupakan mikroorganisme yang bersifat

halofilik sehingga dengan adanya penambahan garam maka bakteri asam laktat masih dapat memfermentasi yang berakibat pada penurunan $\mathrm{pH}$ air rendaman (Adams \& Maurice, 2008).

\section{Pengaruh Perlakuan Rasio Kedelai dan Air Terhadap Mutu Kecambah Kedelai var. Wilis}

Hasil analisis statistik menunjukkan hampir semua data antara kapasitas antioksidan kecambah kedelai var. Wilis terhadap perlakuan rasio kedelai dan air berbeda signifikan $(\mathrm{p}<0.05)$. Gambar 9 menunjukkan bahwa kecambah kedelai var. Wilis dengan kapasitas antioksidan terbaik adalah kecambah yang direndam dengan perbandingan rasio biji kedelai dan air berupa 1:3.

Air dalam jumlah cukup penting dalam proses perkecambahan. Kelebihan maupun kekurangan air merupakan suatu keadaan yang tidak normal karena tanaman akan mengalami cekaman tertentu yang berasal dari luar tubuhnya (Purwandi, 2011).

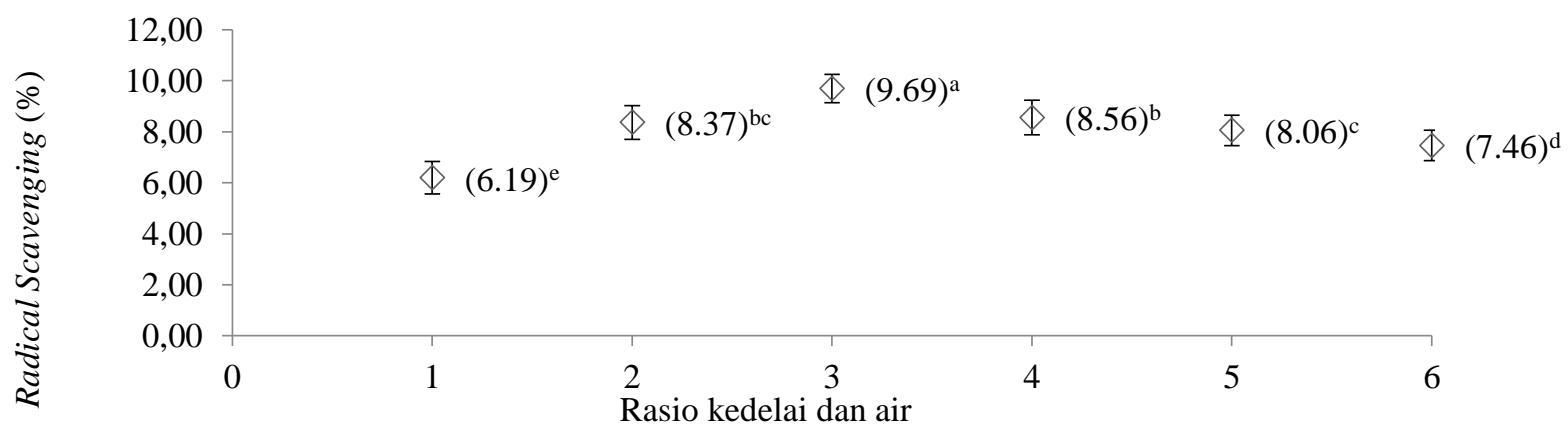

Gambar 9. Pengaruh rasio air rendaman terhadap kapasitas antioksidan kecambah kedelai var. Wilis pada konsentrasi ekstrak kecambah kedelai 100 ppm dengan waktu perendaman 6 jam, suhu perendaman $25^{\circ} \mathrm{C}$, waktu perkecambahan $15 \mathrm{jam}$, suhu perkecambahan $25^{\circ} \mathrm{C}$ dan konsentrasi garam pada air rendaman $0 \mathrm{~g} / \mathrm{L}$. Keterangan: Notasi huruf superscript yang berbeda menunjukkan adanya perbedaan signifikan $(\mathrm{p}<0.05)$

Kelebihan air dapat menyebabkan bakteri asam laktat dapat melakukan fermentasi lebih sehingga dapat menyebabkan akumulasi asam laktat yang berlebih berakibat pada terganggunya proses perkecambahan dari biji kedelai. Di sisi lain, jika tumbuhan mengalami cekaman kekeringan maka jumlah air yang diserap tidak mencukupi dan enzim tidak dapat bekerja secara maksimal (Ai \& Ballo, 2010).
Gambar 10 menunjukkan bahwa laju penyerapan air semakin meningkat seiring dengan ditambahkannya sejumlah air. Hal ini dikarenakan ketersediaan air yang semakin banyak yang memungkinkan biji untuk menyerap lebih banyak air. Namun sama seperti tahapan sebelumnya, laju penyerapan air pada 3 jam pertama lebih tinggi dibandingkan laju penyerapan air 3 jam setelahnya. 


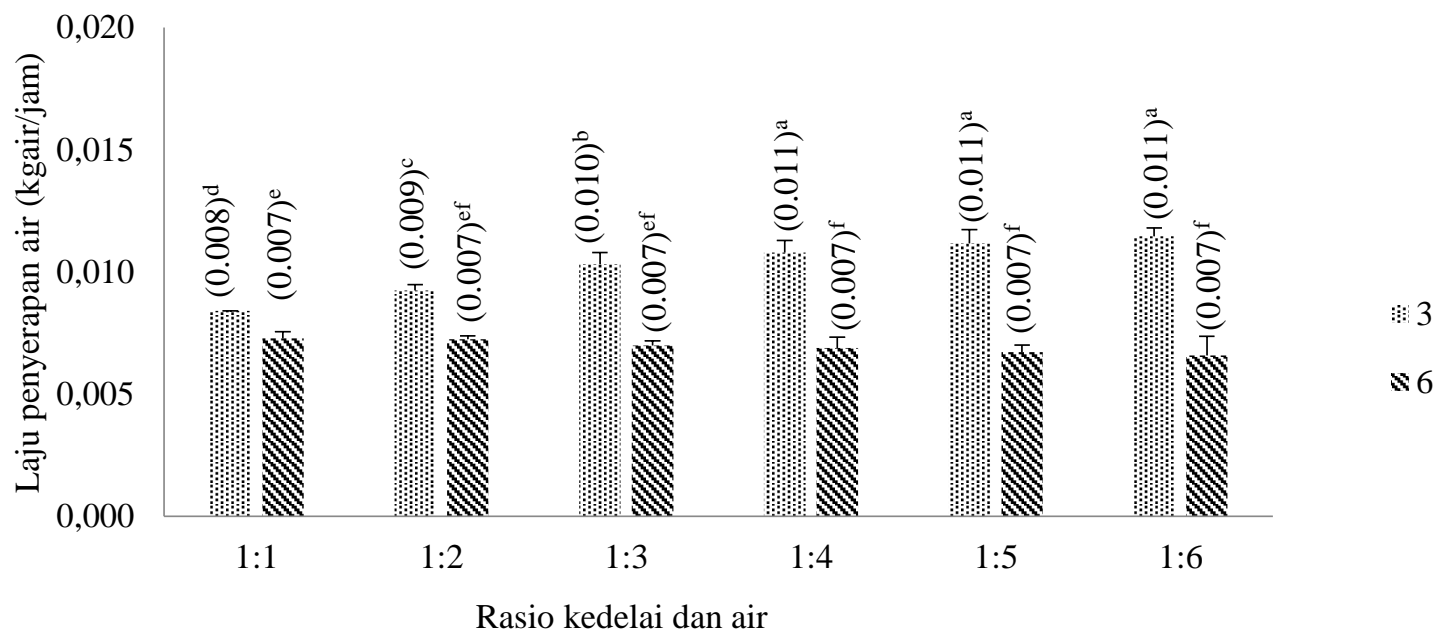

Gambar 10. Pengaruh rasio biji kedelai dan air terhadap laju penyerapan air kecambah kedelai var. Wilis

Gambar 11 menunjukkan pH pada air rendaman terus menurun seiring berjalannya waktu. Hal ini disebabkan oleh terjadinya proses fermentasi oleh bakteri-bakteri asam laktat yang mengakibatkan terbentuknya asam laktat. Semakin banyak air yang tersedia maka semakin besar pula kemungkinan terjadinya pemecahan komponen-komponen dari biji oleh bakteri asam laktat sehingga akhirnya berakibat pada peningkatan tingkat keasaman dan penurunan $\mathrm{pH}$.

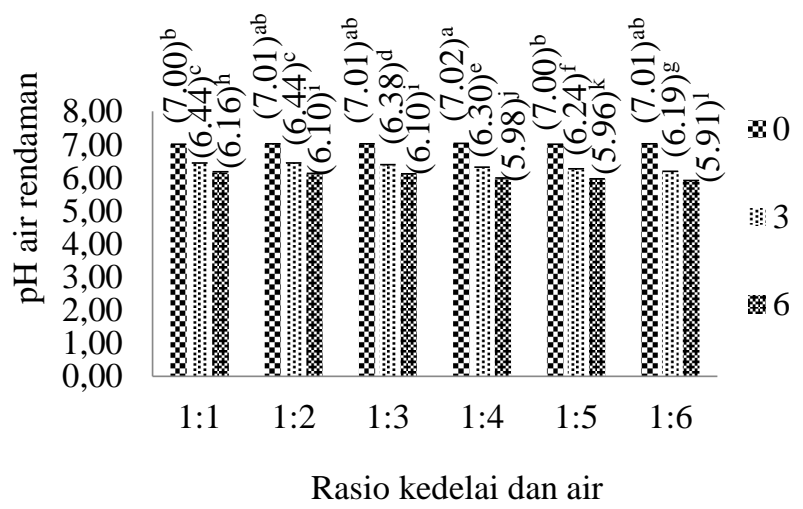

Gambar 11. Pengaruh rasio biji kedelai dan air terhadap pH air rendaman kecambah kedelai var. Wilis

\section{Analisis dengan GC-MS}

Pada hasil identifikasi ekstrak biji kedelai dan kecambah kedelai menggunakan GC-MS tidak semua senyawa yang ditemukan merupakan senyawa antioksidan. Senyawasenyawa antioksidatif yang terdapat di biji kedelai dan kecambah kedelai var. Wilis dapat dilihat pada Tabel 2. Hasil identifikasi menggunakan GC-MS, senyawa dalam ekstrak biji kedelai yang bersifat antioksidatif adalah benzoic acid, 2-methoxy-4-vinylphenol, 2,5-dihydroxytoluene, pyrogallol 1,3-dimethyl ether, 2,5-dihydroxytoluene, pyrogallol 1,3dimethyl ether, hexadecanoic acid methyl ester dan methyl oleate.

Tabel 2. Senyawa antioksidan di dalam biji kedelai dan kecambah kedelai

\begin{tabular}{clcc}
\hline No & \multicolumn{1}{c}{ Nama Senyawa } & $\begin{array}{c}\text { Biji } \\
\text { Kedelai }\end{array}$ & $\begin{array}{c}\text { Kecambah } \\
\text { Kedelai }\end{array}$ \\
\hline 1 & Benzoic acid & $\sqrt{ }$ & $\sqrt{ }$ \\
2 & $\begin{array}{l}\text { 2-Methoxy-4- } \\
\text { vinylphenol }\end{array}$ & $\sqrt{ }$ & $\sqrt{ }$ \\
3 & $\begin{array}{l}\text { 2,5-dihydroxytoluene } \\
4\end{array}$ & $\sqrt{ }$ & $\sqrt{ }$ \\
& $\begin{array}{l}\text { Pyrogallol 1,3- } \\
\text { dimethyl ether }\end{array}$ & $\sqrt{ }$ & $\sqrt{ }$ \\
5 & Neophytadiene & & $\sqrt{ }$ \\
6 & Hexadecanoic acid & & $\sqrt{ }$ \\
& methyl ester & $\sqrt{ }$ & $\sqrt{ }$ \\
7 & (palmitic acid) & Methyl oleate & $\sqrt{ }$ \\
8 & Campesterol & & $\sqrt{ }$ \\
9 & Stigmasterol & & $\sqrt{ }$ \\
10 & delta-Tocopherol & & $\sqrt{ }$ \\
11 & gamma-Tocopherol & & $\sqrt{ }$ \\
\hline
\end{tabular}

Senyawa dalam ekstrak kecambah kedelai yang bersifat antioksidatif sama seperti senyawa dalam ekstrak biji kedelai namun terdapat beberapa tambahan seperti neophytadiene, campesterol, stigmasterol, delta-tocopherol dan gamma-tocopherol. Adanya senyawa yang hilang setelah proses perkecambahan dapat disebabkan oleh terjadinya proses hidrolisis selama proses 
perendaman dan perkecambahan (Sukatiningsih et al., 2013). Hal ini mungkin terjadi karena adanya senyawa dan mineral yang terlarut dalam air. Namun, selama proses perkecambahan juga terjadi perubahan pada senyawa-senyawa tersebut akibat adanya proses sintesis. Proses ini kemudian akan menghasilkan senyawa metabolit primer dan metabolit sekunder.

\section{Kandungan Total Fenol}

Kandungan total fenol pada biji kedelai var. Wilis adalah $2.1 \mathrm{mg}$ GAE/g sampel sedangkan kandungan total fenol setelah biji kedelai var. Wilis dikecambahkan adalah 2.9 mg GAE/g sampel dilihat pada Gambar 12.

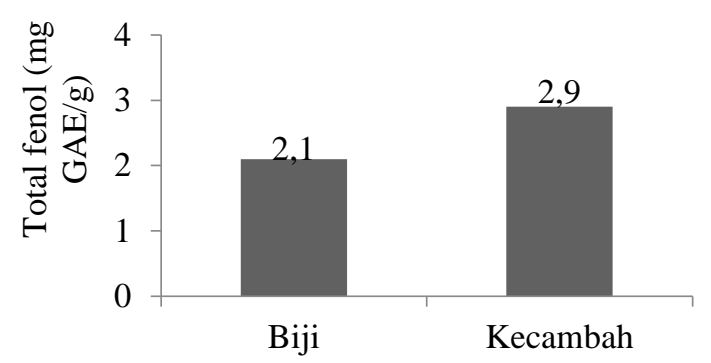

Gambar 12. Perbandingan kandungan total fenol pada biji dan kecambah kedelai var. Wilis

Peningkatan senyawa fenol dapat terjadi karena selama proses perkecambahan terjadi sintesis enzim dari $\beta$-glukosidase yang diproduksi oleh mikroorganisme selama proses fermentasi dan perkecambahan terjadi. Enzim ini memainkan peranan penting dalam memotong ikatan glukosa atau oligosakarida tertentu dan membebaskan senyawa fenolik dalam proses fermentasi (Hsieh \& Graham, 2001). Peningkatan senyawa fenolik juga dapat terjadi akibat adanya eliminasi molekul ammonia dari asam sinamat yang dikatalis oleh phenylalanine ammonia lyase (Setyorini \& Yusnawan, 2016). Phenylalanine ammonia lyase berperan penting dalam pembentukan lignin, suberin, phytoalexins, stilbenes, coumarins, dan senyawa flavonoid lainnya melalui jalur phenylpropanoid.

\section{KESIMPULAN}

Optimasi kapasitas antioksidan kecambah kedelai var. Wilis dapat dilakukan dengan cara perkecambahan pada suhu $25^{\circ} \mathrm{C}$ selama 15 jam dengan rasio biji kedelai dan air 1:3 tanpa adanya penambahan garam. Terdapat senyawa-senyawa antioksidan baru yang muncul setelah proses perkecambahan yaitu neophytadiene, campesterol, stigmasterol, delta-tocopherol dan gamma-tocopherol. Kandungan total fenol juga meningkat setelah proses perkecambahan dilakukan.

\section{DAFTAR PUSTAKA}

Adams, M, \& Maurice, O. M., 2008. Food Microbiology Third Edition. RSC Publisihing: Guildford.

Ai, N. S. \& Ballo, M., 2010. Peranan Air dalam Perkecambahan. Jurnal Ilmiah Sains, 10(2), Hal.190-195.

Astawan, M., 2009. Sehat dengan Hidangan Kacang dan Biji-Bijian. Penebar Swadaya: Jakarta.

Cevallos-Casals, B. \& Cisneros-Zevallos, L., 2010. Impact of Germination on Phenolic Content and Antioxidant Activity of 13 Edible Seed Species. Food Chem, 119(4), p.1485-1490.

Ginting, E., S. S. Antarlina \& S. Widowati. 2009. Varietas Unggul Kedelai Untuk Bahan Baku Industri Pangan. Jurnal Litbang Pertanian, 28(3), Hal.79-87.

Hsieh, M. C. \& Graham, T. L., 2001. Partial Purification and Characterization of a Soybean Beta-Glucosidase with High Specific Activity Towards Isoflavones Conjugates. Phytochemistry, 58(7), p.9951005.

Huang, X., Cai, W. \& Xu, B., 2014. Kinetic Changes of Nutrient and Antioxidant Capacities of Germinated Soybean (Glycine max L.) and Mung Bean (Vigna rodiata L.) with Germination Time. Food Chemistry, 143(1), p.268-276.

Kim, W. J., Lee, H. Y., Won, M. H. \& Yoo, S. H., 2005. Germination Effect of Soybean on its Content of Isoflavones and Oligosaccharides. Food Science and Biotechnology, 14(4), p.498-502.

Larcher, W., 2003. Physiological Plant Ecology: Ecophysiological and Stress 
Physiology of Functional Groups. Springer: Berlin.

Narsih, Y. \& Harijono., 2008. Studi Lama Perendaman dan Lama Perkecambahan untuk Menghasilkan Tepung Rendah Tanin dan Fitat. Jurnal Teknologi Pertanian, 9(3), Hal. 173-180.

Nurdini, A. L., Nuraida, L., Suwanto, A. \& Suliantari. 2015. Microbial Growth Dynamics during Tempe Fermentation in Two Different Home Industries. International Food Research Journal, 22(4), p.1668-1674.

Pan, Z. \& Tangratanavalee, W., 2003. Characteristics of Soybeans as Affected by Soaking Conditions Lebensm.-Wiss. U.Technol, 36(1), p.143-151.

Plaza, I., B. Ancos \& Cano, M. P., 2003. Nutritional and Health-Related Compounds in Sprouts and Seeds of Soybean (Glycine max), Wheat (Triticum aestivum L.) and Alfalfa (Medicago sativa) Treated by A New Drying Method. European Food and Research Technology, 216(1), p.138-144.

Purwandi, E. 2011. Seleksi Benih Tahan Kering melalui Uji PEG. [online] Tersedia di: http://www.masbied.com.pdf [diakses pada tanggal 4 November 2017].
Rosmarkam, A. \& Yuwono, N. W., 2002. Ilmu Kesuburan Tanah. Kanisius: Yogyakarta.

Setyorini, S. D. \& Yusnawan, E., 2016. Peningkatan Kandungan Metabolit Sekunder Tanaman Aneka Kacang sebagai Respon Cekaman Biotik. Iptek Tanaman Pangan, 11(2), Hal.167-174.

Shafaei, S. M., Masoumi, A. A., \& Roshan, H., 2016. Analysis of Water Absorption of Bean and Chickpea during Soaking using Peleg Model. Journal of the Saudi Society of Agriculture Sciences, 15(2), p.135-144.

Sukatiningsih, A. M. Yustian \& S. W. Windrati. 2013. Penambahan Isolat Protein Kedelai dan Sukrosa Elisitor terhadap Senyawa Antioksidan dan Racun pada Kecambah Koro Kratok [Phaseolus lunatus (L) Sweet]. Agritrop Jurnal Ilmu-Ilmu Pertanian. 11(1): 7-13.

Wachid, M, 2006. Optimalisasi Zat Gizi pada Proses Perkecambahan Pembuatan Taoge: Kajian Suhu dan Lama Perendaman. GAMMA, 1(2), Hal.112-117.

Wardani, K. E., Mantiri, F. R. Ai, N. S. \& Rumondor, M., 2014. Kajian Ethylene Triple Response terhadap Kecambah Tiga Varietas Kedelai. Jurnal Bioslogos, 4(2), Hal.77-82. 